\title{
SOROTAN ALKITABIAH \\ TERHADAP KONSEP KESELAMATAN MENURUT JOHN HICK
}

\author{
Dora Hutasoit
}

\section{PENDAHULUAN}

\begin{abstract}
Dalam tulisan ini akan dibahas mengenai "Sorotan Alkitabiah Terhadap Teori Keselamatan Menurut John Hick". Menurut Hick, di setiap agama memiliki orang salehnya sendiri, yaitu mereka yang sudah mengalami transformasi dari selfcenteredness kepada Reality-centeredness. Hal itu nampak dari kualitas atau kematangan kehidupan rohani mereka, misalnya seperti: ketabahan, damai sejahtera dalam hati, sukacita, kebaikan dan seterusnya. Dengan demikian keselamatan atau transformasi Hick di sini lebih ditekankan pada transformasi etis daripada penebusan umat manusia. Oleh sebab itu, menurut Hick, bahwa eksklusivisme yang mengklaim bahwa keselamatan hanya ada di dalam dan melalui Kristus tidak dapat diterima, karena Allah yang kasih itu mencari dan menghendaki seluruh umat manusia selamat.

Berdasarkan keselamatan yang bersifat universal ini, maka menurut Hick, keselamatan itu sama dan diperuntukkan bagi semua orang. Jadi keselamatan itu dapat terjadi bukan dengan pengertian diinjili dan harus bertobat.
\end{abstract}

\section{BAB I}

\section{LATAR BELAKANG JOHN HICK DAN PERKEMBANGAN FILSAFAT AGAMA/TEOLOGINYA}

Biografi John Hick dan perkembangan filsafat agama atau teologi dari John Hick.

\section{$\underline{\text { Biografi John Hick }}$}

John Hick dibesarkan di lingkungan gereja Anglikan di Inggris. Dia studi di bidang filsafat dan tertarik pada filsafat Kant (yang di kemudian hari ikut mempengaruhi pola pikirnya), walaupun waktu itu ia masih aktif mengikuti kegiatan Kristen dan mengaku sebagai seorang Injili. Dia menyelesaikan doktor filsafatnya di Universitas Oxford (di sini dia dipengaruhi oleh H. H. Price). Dia adalah seorang filsuf agama dan teolog. Kemudian hari ia berpaling dari penganut Injili kepada penganut pluralis. Peristiwa ini baginya merupakan peralihan cara berpikirnya atau pandangan teologinya, dari paham Ptolomeus (berpusat kepada bumi/Kristus) yang 
dianggapnya kemudian keliru, kepada Kopernikus (berpusat pada matahari/"Allah" atau Realitas). Bahkan dia adalah seorang tokoh terkemuka dalam pluralis. Hipotesehipotese teologinya senantiasaa bersifat pluralistik. ${ }^{1}$

\section{Perkembangan Filsafat Agama/Teologi John Hick}

Sebagai kaum pluralis yang teosentris, dia menolak dogma Kristen yang menurutnya lebih berpusat pada Kristus dan yang menyatakan bahwa hanya orang Kristen yang dapat diselamatkan. Menurut Hick, orang-orang yang bukan Kristen sebenarnya adalah orang-orang Kristen yang tidak menyadari bahwa dirinya Kristen, sehingga mereka juga dapat diselamatkan.

Dengan perubahan cara berpikirnya, yang diumpamakan sebagai perpalingan dari teologi Kristen Ptolomeus (berpusat pada Kristus) kepada teologi Kopernikus (berpusat pada Allah), yaitu yang menganggap bahwa seluruh agama berpusat pada Allah dan bukan pada "Kristus saja", atau pada agama Kristen atau pada salah satu agama lain.

Untuk mempertahankan teori/pendapatnya, Hick menafsirkan kembali kristologi kekristenan. Ia menolak keunikan Kristus (misalnya: "Aku dan Bapa adalah satu", Yoh. 10:30). Bagi dia inkarnasi Yesus hanyalah mitos semata. Demikian juga peristiwa kejatuhan manusia ke dalam dosa, anugerah dan keselamatan oleh penebusan darah Kristus, surga dan neraka, bagi dia hanyalah mitos dan produk imajinasi keagamaan (hasil pemikiran Hellenistis) yang mustahil dipercaya oleh orang berpendidikan. Maka Allah sebagaimana cermin dalam aneka ragam kebudayaan menjadi nyata dalam wahyu-wahyu atau agama-agama yang berbeda. Jadi walaupun ada perbedaan di antara bermacam-macam wahyu, namun Allah yang Esa sedang bekerja mencetak pada jiwa manusia. ${ }^{2}$ Kita tidak boleh memisahkan penciptaan atau penebusan, tetapi melihat eksistensi manusia pada saat ini, merupakan suatu proses tingkat penciptaan makhluk terbatas yang harus hidup dalam kesadaran relasi dengan Allah (Realita).

Jadi menurut Hick, kehidupan manusia, baik Kristen maupun non Kristen merupakan suatu proses menuju kepada penyempurnaan jiwa (soul making), yaitu suatu kesempurnaan sebagaimana yang dimaksudkan Allah Pencipta bagi setiap orang dalam kehidupan keagamaannya masing-masing. ${ }^{3}$ Proses kesempurnaan itu menurut Hick berlangsung selama kehidupan manusia, dan jalan ini dapat disamakan dengan jalan keselamatan yang dialami oleh masing-masing agama. Menurut Hick, proses keselamatan itu dialami melalui suatu transformasi eksistensi manusia, dan jalan pikirannya itu akan diuraikan lebih jelas dalam bab berikut ini.

\footnotetext{
${ }^{1}$ David Ndoen, Pluralisme, Diktat, (Batu: STT “I-3”, 1996), 45; (Bagi kaum pluralis, semua agama memiliki jalan soteriologis yang setara).

${ }^{2}$ Harold Coward, Pluralisme, Tantangan Bagi Agama-agama, (Yogyakarta: Kanisius, 1992), $57-60$

${ }^{3}$ David Ndoen, Pluralisme..., 45
} 


\section{BAB II}

\section{ARTI KESELAMATAN MENURUT JOHN HICK}

Keselamatan menurut Hick adalah transformasi eksistensi manusia dari berpusat pada diri sendiri (self-centeredness) kepada berpusat pada Realitas Tertinggi (Reality-centeredness). Untuk dapat mengerti jalan pikirannya tentang keselamatan ini, kita akan melihat tahapan pikirannya berikut ini.

\section{Teologi Kopernikus John Hick}

Setelah terjadi perubahan cara berpikir Hick, maka pandangan teologinya beralih dari paham Ptolomeus kepada paham Kopernikus yang merupakan suatu transformasi radikal dari posisi teologis "Kristosentris" kepada "Theosentris". Dengan demikian Hick menolak dengan tegas inklusivisme kaum Protestan liberal dan pluralis inklusif yang masih terikat pada finalitas Kristus. Dengan paham theosentrisnya, membawa pandangan Hick pada persamaan fenomena semua agama dan konsep soteriologis masing-masing agama. ${ }^{4}$

Sebagai konsekuensi transformasi kepada teologi theosentris, Hick menolak Kristus yang historis. Inkarnasi Yesus Kristus menurutnya harus dipahami sebagai mitologi dan hanyalah figuratif bagi orang Kristen untuk mengatakan bahwa Yesus adalah mediator manusia Allah. Dengan demikian Yesus bukanlah jalan satu-satunya yang paling efektif bagi manusia untuk berkomunikasi dengan Allah. Dengan kata lain, Yesus bukanlah satu-satunya jalan keselamatan.

Mengenai penggunaan istilah "Allah", menurut Hick bukanlah mengacu kepada Tuhan yang berpribadi sebagaimana yang dipakai oleh agama teistis, tetapi itu mengacu kepada "Realitas Tak Terbatas/Tertinggi" sebagaimana dipahami dengan berbagai cara melalui beragam bentuk pengalaman beragama, seperti yang dijelaskannya sebagai berikut:

Saya telah mencoba menggunakannya (istilah "Allah") sedemikian rupa sehingga sudah pada tempatnya apabila mengajukan pertanyaan apakah Allah adalah pribadi. Namun saya mengakui bahwa penggunaan istilah ini dapat dengan mudah menimbulkan kesalah-pahaman. Oleh karena itu saya lebih suka menggunakan istilah "Yang Nyata", dan membedakan antara pengalaman manusia mengenai Yang Nyata sebagai pribadi (bentuk konkretnya seperti Yahwe, Shiva, Vishnu, Bapa Surgawi dll.), dan pengalaman manusia Yang Nyata sebagai bukan pribadi (bentuk konkretnya seperti Brahma, Tao, Dharma, Nirvana, Sunyata, dll). ${ }^{5}$

${ }^{4}$ David Ndoen, Mengenal Selintas Soteriologi Pluralisme, dalam K. Hadiwinoto, Pendidikan Teologi Injili Suatu Alternatif?, (Malang: Tunggal Murni, 1995), 61

${ }^{5}$ Harold Coward, Pluralisme, Tantangan bagi Agama-agama..., 60 
Jadi menurut Hick, istilah "Allah" harus dipahami sebagai Realitas Tertinggi, baik itu Allah yang berpribadi maupun yang tidak berpribadi (sesuai agama-agama atheis). Dengan demikian "Allah" tidak dapat dikenal karena melampaui pikiran manusia. Dan hanya fenomena Realita Tertinggi yang dapat dikenal di balik semua agama.

\section{Transformasi Eksistensi Manusia dari Self-Centeredness Kepada Reality- Centeredness}

Sebagai pengaruh teori Kopernikus, maka dalam konsepsinya bahwa agamaagama yang berbeda mempunyai kesetaraan secara soteriologis. Itu berarti ada suatu perpalingan dari dogma Kristen. Semula kekristenan atau Kristus sebagai pusat dari semua agama atau kepercayaan.

Dengan demikian menurut Hick, kekristenan harus mempunyai suatu pemahaman keselamatan yang didasarkan pada tindakan penebusan secara yuridis (dasar pemahaman dogma Kristen) kepada keselamatan yaitu: "Transformasi eksistensi manusia dari self-centeredness kepada reality-centeredness".

Dari teori keselamatan Hick ini menyebabkan tidak dibutuhkan lagi seorang Juruselamat yang menebus dosa manusia. Doktrin Kristen tentang penebusan dosa manusia diganti dengan apa yang disebutnya "soul making" atau "penyempurnaan jiwa", yaitu sistem keselamatan yang tidak memisahkan penciptaan dengan penebusan. ${ }^{6}$

Menurut Hick, cara mencapai kesempurnaan atau jalan keselamatan itu terjadi dalam waktu yang lama, bahkan selama hidup manusia. Dan setiap agama menyediakan jalan yang efektif dan benar untuk keselamatan. Setiap klaim merupakan suatu konteks yang efektif yang di dalamnya transformasi eksistensi manusia dapat terjadi, yaitu dari sifat yang berpusat pada diri sendiri kepada yang berpusat pada Realitas. Maka menurut Hick, seharusnya kita menerima hal ini dengan sukacita karena Realitas Tertinggi mempengaruhi kesadaran manusia untuk pembebasan atau keselamatan dengan berbagai cara di dalam berbagai bentuk kehidupan bangsa dan agama. $^{7}$

\footnotetext{
${ }^{6}$ Lihat Bab I

${ }^{7}$ David Ndoen, Pluralisme..., 68
} 


\section{BAB III}

\section{SOROTAN ALKITABIAH}

Di dalam bab ini akan dilakukan evaluasi alkitabiah terhadap beberapa pandangan John Hick, yaitu:

\section{Sorotan Alkitabiah terhadap Revolusi Kopernikus John Hick}

"Revolusi Kopernikus" adalah istilah yang dipakai oleh kaum pluralis untuk menggambarkan adanya peralihan paradigma atau transformasi radikal dari posisi teologis "Kristosentris" kepada "Theosentris". ${ }^{8}$ Sebagai konsekuensi logis dari peralihan paham ini bagi Hick adalah bahwa ia menolak dengan tegas semua paham Kristosentris, baik eksklusivisme, inklusivisme, maupun universalisme kaum Protestan liberal, dan hanya mau menerima paham Theosentris.

Yang hendak kita lihat di sini adalah apa yang dimaksud dengan "berpusat pada Allah", "Allah" yang bagaimana, apakah sama dengan Allah kekristenan atau ilah-ilah lain? ${ }^{9}$ Untuk hal ini, Hick mencoba memecahkannya dengan jalan sebagai berikut: Ada tiga kemungkinan yang Hick pikirkan: pertama, secara ontologis terdapat banyak allah atau dewa/i. Namun ini menimbulkan konflik klaim dari setiap kepercayaan bahwa Allah atau dewa/i (mereka) adalah pencipta semesta. Kemungkinan kedua, ialah hanya satu agama yang menyembah Allah dan lainnya menyembah berhala.

Hick menolak kedua kemungkinan di atas dan mengusulkan alternatif yang ketiga yang dapat diterimanya ialah: Hanya satu Allah yang disembah, yaitu Pencipta dan Tuhan untuk semua, yang di dalam kepenuhan ketidakterbatasan dan kekayaan keberadaan-Nya di dalam pikiran, sehingga manusia berbakti kepada-Nya dalam berbagai bentuk agama. Namun pada kenyataannya menyembah Allah yang sama, tetapi melalui konsep-konsep dan gambaran mental yang tumpang tindih. ${ }^{10}$

Nampak sekali di sini Hick berusaha untuk mempertahankan paham teosentrisnya yang diberlakukan bagi semua agama, walaupun sebenarnya sangat sulit atau cenderung dipaksakan. Namun bila kita evaluasi atau kita soroti dari apa yang dikatakan Alkitab, baik dari Perjanjian Lama maupun dari Perjanjian Baru, pikiran Hick itu sangat bertentangan. Agama-agama dengan praktek penembahan kepada semua ilah-ilah atau dewa-dewa, sudah ada sejak zaman Perjanjian Lama maupun Perjanjian Baru, dan bahkan sampai sekarang. Dan justru Tuhan sangat tegas memperingatkan atau menentang agar umat Israel tidak menyembah atau berbakti kepada ilah-ilah lain kecuali kepada YHWH (Kel. 20) dan tidak ada Allah lain kecuali YHWH (Yes. 44:6,8; 45:5,6,18,22; 49:9). Demikian juga dalam

\footnotetext{
${ }^{8}$ David Ndoen, Mengenal Selintas ..., 61

${ }^{9}$ Wilfred C. Smith, Idolatry in Comparative Perspective dalam John Hick \& P. F. Knitter (ed.), The Myth of Christian Uniqueness, (London: SCM Press Ltd., 1988), 66-67

${ }^{10}$ David Ndoen, Mengenal Selintas ..., 61-62
} 
Perjanjian Baru, Paulus menasihati orang-orang di Listra agar meninggalkan perbuatan sia-sia itu, yaitu penyembahan berhala atau dewa-dewa, dan berpaling kepada Allah yang hidup dan benar, yang disebut Injil oleh Paulus (Kis. 14:15). Paulus juga melukiskan orang yang bertobat dari pluralisme sebagai orang yang berbalik dari berhala-hala kepada Allah yang hidup dan benar (band. 1 Tes. 1:19).

Demikian juga pada zaman sekarang ada banyak pandangan kompromi yang ingin mengkompromikan penyembahan kepada Allah melalui bermacam-macam cara atau paham atau pandangan agama atau kepercayaan, misalnya: dengan jalan dialog agama, toleransi agama, penyesuaian kebudayaan dan seterusnya. Tetapi Tuhan tidak menghendaki kompromi. Firman Tuhan mengatakan bahwa Dia adalah Allah yang cemburu (Kel. 20:5; 34:14; 1 Kor. 10:22), dan Ia menghendaki kita mengasihi atau menyembah Dia dengan segenap akal budi kita (Mat. 22:37).

Dengan demikian klaim Hick atau pluralis yang mengatakan bahwa revolusi Kopernikus dengan teosentrisnya-lah yang berada dalam orbit yang benar, dan juga bahwa semua agama menyembah kepada "Allah" yang sama dan berakhir pada tujuan (keselamatan) yang sama, tidak dapat diterima, bahkan harus ditolak karena tidak didasari oleh kebenaran Alkitab, bahkan sangat menyimpang dari Firman Tuhan. Firman Tuhan mengatakan bahwa roh yang demikian adalah roh antikristus (1 Yoh. 4:3).

Juga perlu dievaluasi atau disoroti secara alkitabiah mengenai penolakannya terhadap paham Ptolomeus yaitu yang berpusat pada Kristus atau kekristenan. Di sini Hick berusaha mempertahankan pendiriannya dengan menafsirkan kembali Kristologi tradisional. Dia menghilangkan atau menolak penegasan alkitabiah mengenai Kristus yang absolut, unik dan final, atau Yesus Kristus yang eksklusif, seperti yang diungkapkan dalam Firman Tuhan atau oleh Yesus sendiri: "Aku dan Bapa adalah satu" (Yoh. 10:30).

Hal ini dipahami oleh orang Yahudi bahwa Yesus menyamakan diri-Nya dengan Allah (Yoh. 10:33), sehingga mereka hendak melempari Yesus dengan batu. Demikian juga kesaksian Injil Yohanes bahwa Firman yang tadinya bersama-sama dengan Allah (Yoh. 1:1), Firman itu juga telah menjadi Manusia (Yoh. 1:14). Dia adalah sungguh-sungguh Allah dengan segala keilahian-Nya tetapi dalam waktu yang sama, Dia juga sungguh-sungguh manusia, tinggal di antara kita. Dia-lah Kristus yang unik. ${ }^{11}$

Penegasan Allah mengenai diri-Nya, yaitu: "Aku Tuhan" dan "Aku tetap Dia”, adalah sama dengan "Aku-lah Dia", yaitu sebagai bentuk singkat dari ungkapan khusus yaitu: "Aku-lah YHWH". "Aku adalah" atau "Aku-lah Dia", "Yang terdahulu dan Yang terkemudian" (Yes. 41:4; 44:6,8, dst). Dia YHWH adalah yang pertama, tidak mempunyai silsilah (band. Yes. 43:10) dan juga yang terakhir. Penegasan seperti ini khusus meyakinkan bahwa YHWH-lah Allah yang satu-satunya. Penegasan yang sama juga diungkapkan oleh Yesus dengan pernyataan "Aku Adalah" ( $\dot{\varepsilon} \gamma \omega \dot{\varepsilon} \mu \mathrm{l}=$ ego emi).

Yang sangat menarik adalah bahwa Yesus mengungkapkan diri-Nya dengan ungkapan yang sama dengan yang ada dalam kitab Yesaya, yaitu yang hanya digunakan oleh Allah sendiri. Suatu ungkapan yang begitu erat, menyamakan diri-

${ }^{11}$ Andrew D. Clark, Satu Allah, Satu Tuhan, (Jakarta: BPK Gunung Mulia, 1995), 65 
Nya dengan karya penyelamatan YHWH, bahkan dengan YHWH sendiri (band. Yoh. 10:30). ${ }^{12}$

Ungkapan Tuhan Yesus lainnya yang senada antara lain: "Aku adalah jalan satu-satunya" (Yoh. 14:16), "Aku-lah Gembala yang baik" (Yoh. 10:10), "Aku-lah Pokok Anggur yang benar" (Yoh. 15:1), "Aku-lah pintu; barangsiapa masuk melalui Aku, ia akan selamat" (Yoh. 10:9), dst. Tidak ada seorang pun yang dapat memakai gelar-gelar itu. Sama seperti dalam pengakuan Nicea, berarti Allah dapat dikenal dan ditanggapi melalui Yesus. Dengan demikian semua agama di luar kepercayaan Kristen, berada di luar lingkup penyelamatan Allah. ${ }^{13}$

Oleh sebab itu penolakan Hick terhadap paham Ptolomeus atau dogma kekristenan, tidak dapat dibenarkan, karena sebenarnya Kristus adalah sama dengan Allah sendiri, sedang teologi Hick tidak mempunyai landasan Alkitab dan iman Kristen.

\section{Sorotan Alkitabiah \\ terhadap Teori Keselamatan John Hick}

Hick merumuskan keselamatan adalah merupakan transformasi eksistensi manusia dari berpusat pada diri sendiri kepada berpusat pada Realitas Tertinggi. Melalui rumusan ini, berarti bahwa seharusnya kekristenan segera meninggalkan orbitnya yaitu Kristus sebagai pusat, dan beralih kepada "Allah"/ Realitas Tertinggi sebagai pusat dari semua agama atau kepercayaan.

Sebelumnya sudah dibahas bahwa "Allah"-nya Hick yang dinyatakan sebagai Realitas Tertinggi dari semua agama, tidaklah sama dengan Allah YHWH seperti yang dinyatakan dalam Alkitab. Sekarang kita akan mengevaluasi secara alkitabiah tentang teori keselamatan Hick. Dengan rumusan keselamatan Hick itu, berarti bahwa kekristenan dituntut untuk memiliki perspektif dan pemahaman baru tentang keselamatan yaitu: "Berpindah dari pemahaman keselamatan yang didasarkan pada tindakan penebusan secara yuridis kepada keselamatan yaitu transformasi eksistensi atau pengalaman manusia, dari berpusat pada diri sendiri kepada berpusat pada Realitas".

Rumusan ini mengungkapkan bahwa tidak dibutuhkan lagi seorang Juruselamat yang menebus dosa manusia, sebagai tindakan yuridis, karena setiap agama dan tradisi agama atau kepercayaan lainnya telah menyediakan jalan keselamatannya masing-masing, hanya saja tindakan keselamatannya berasal dari "Allah" atau Realitas Tertinggi yang satu itu. ${ }^{14}$

Karena keselamatan tidak dapat dipisahkan dengan masalah dosa, maka terlebih dulu dalam bagian berikut ini akan dievaluasi atau disoroti apa arti dosa menurut Firman Tuhan.

\footnotetext{
12 Ibid.

${ }^{13}$ Ibid, 67-68

${ }^{14}$ David Ndoen, Pluralisme...., 90
} 


\section{$\underline{\text { Sorotan Alkitabiah terhadap arti dosa menurut Hick }}$}

Van Niftrik dalam bukunya Dogmatika Masa Kini menjelaskan tentang dosa sebagai berikut: Dosa tidak selalu sama dengan kejahatan, karena perbuatan baik dapat juga merupakan dosa, misalnya orang Farisi adalah orang-orang berdosa pada pandangan Allah, walaupun pada pandangan manusia mereka adalah orang-orang jujur, taat kepada agama, tetapi mereka menolak kasih dan rahmat Allah yang dinyatakan melalui kedatangan Yesus Kristus ke dalam dunia.

Dosa tidak boleh dijadikan istilah etika manusia. Dosa adalah istilah teologia yang ada kaitannya dengan hubungan manusia dengan Allah. Dosa menyebabkan terputusnya hubungan manusia dengan Allah dan secara sadar melakukan pelanggaran terhadap kehendak Allah (band. Kej. 3). ${ }^{15}$ Dosa menurut firman Tuhan adalah: membenci Allah (Yoh. 15:23, 24), hidup tanpa Allah (Luk. 15:11 dst.), tidak layak disebut anak-anak Allah (Luk. 15:21), dosa adalah permusuhan dengan Allah (Rom. 5:6-12), dosa juga mengakibatkan kehilangan kemuliaan Allah (Rom. 3:23). Oleh karena dosa, manusia di luar standar Allah, sehingga manusia berada di luar kehidupan yang kekal.

Berbeda sekali dengan pandangan Hick, bahwa dosa adalah kekurangdewasaan, yang lebih menekankan pada etika atau moral. Oleh sebab itu berdasarkan Firman Tuhan, tindakan manusia berdosa bukanlah sekedar kelemahan atau kekurang-dewasaan atau ketidak-sempurnaan dan sedang dalam proses kesempurnaan sebagaimana pandangan Hick, melainkan dosa adalah suatu tindakan aktif, suatu kerusakan manusia dari dalam dan pemberontakan terhadap Allah. Manusia sendiri tidak dapat membebaskan diri dari hukuman karena dosa. Manusia membutuhkan seorang Juruselamat untuk membebaskannya dari dosa dan penghukuman yang dahsyat (band. Ibr. 10:4; 1 Kor. 15:3; Yoh. 1:29, dll). Alkitab dengan jelas menyatakan betapa seriusnya penghakiman Allah terhadap manusia berdosa dan pembuat kejahatan (band. Nah. 1:2-8; Luk. 21:22-24; Rom. 1:18, 2:5, 5:9, 12:4, 13:4; 1 Tes. 1:10, 2:16, 5:9; 2 Tes. 1:10; Wah. 6:16, dst., 16:14).

Kita sudah membahas dan melihat adanya perbedaan atau pertentangan paham mengenai dosa menurut firman Tuhan atau dogma Kristen dan menurut Hick. Berikut ini kita akan menyoroti arti keselamatan Hick dari segi Alkitab.

\section{$\underline{\text { Sorotan Alkitabiah terhadap Keselamatan Menurut John Hick }}$}

Teori keselamatan John Hick yaitu: Transformasi eksistensi manusia dari berpusat pada diri sendiri kepada berpusat pada Realitas Tertinggi. Menurut pandangan Hick, bahwa setiap agama mempunyai jalan keselamatannya masingmasing, atau dengan kata lain bahwa keselamatan dalam semua agama dilaksanakan oleh Realitas Tertinggi. Setiap agama atau kepercayaan lain memakai lambang atau konsep teologis yang berbeda-beda (seperti misalnya: "Allah", "Dewa", "Kebenaran Ilahi", "Realitas Tertinggi", dsb.). Walaupun dengan keperbedaan itu, namun mereka dari semua agama dapat bertemu dengan Realitas Tertinggi dan memperoleh

15 G. C. van Niftrik, Dogmatika Masa Kini, (Jakarta: BPK Gunung Mulia, 1907), 355 
keselamatan. Newbigin menjelaskan masalah "keselamatan" tersebut sebagai berikut:

Langkah lebih jauh dijelaskan sebagai "soteriosentris". Dia mempunyai pusatnya dalam pencarian bersama tentang keselamatan. "Realitas Tertinggi" tidak diidentifikasikan dengan sesuatu nama atau gambar atau cerita yang khusus. "Realitas" tidak mempunyai bentuk, kecuali pengetahuan kita tentang Dia. "Realitas" juga tidak dapat dikenal dan masing-masing kita harus membentuk gambarnya sendiri tentangnya. Tidak ada kenyataan obyektif yang dapat menentang diri sendiri dan menawarkan "pusat" yang lain. (Berbeda dengan yang dilakukan oleh pribadi Yesus yang konkrit).

Dalam hal ini yang ada hanyalah "diri sendiri" (self-centeredness) dan kebutuhan untuk keselamatan, yaitu suatu kebutuhan yang harus puas dengan bentuk apa saja dari Transenden yang tidak dikenal di mana dirinya dapat menghargainya. ${ }^{16}$

Kalau kita mengikuti jalan pikiran ini, sungguh merupakan suatu perbuatan memutarbalikkan tradisi atau dogma kekristenan tentang keselamatan yang oleh Newbigin diungkapkan sebagai berikut:

Keselamatan ini sudah dimungkinkan oleh karena Allah, pencipta dan penampung semua yang ada, yang sudah bertindak dalam pribadi historis dari Manusia Yesus untuk menjumpai kita, mengambil beban dosa dan kematian kita, mengundang kita untuk mempercayakan diri dan mengasihiNya, dan dengan demikian datang kepada kehidupan yang berpusatkan dalam Allah dan tidak dalam dirinya sendiri. ${ }^{17}$

Sesuai rumusan keselamatan menurut Hick maka ia menolak rumusan tradisi kekristenan ini. Rumusan keselamatan Hick (soteriosentris) ini, oleh Feuerbach diungkapkan bahwa "Allah"nya Hick yang dipahami sedemikian hanyalah merupakan gambaran sendiri yang berlebihan; yang merupakan kemenangan terakhir dari manusia atas kenyataan. Suatu pandangan "soteriosentris" membuat "kenyataan" menjadi pelayan dari diri sendiri dan keinginan-keinginannya. ${ }^{18}$

Berikut ini beberapa kutipan tentang keselamatan menurut Alkitab:

Tuhan adalah terangku dan keselamatanku (Maz. 27:1); Sungguh, Allah itu keselamatan (Yes. 12:2); Sebab mataku telah melihat keselamatan yang daripada-Mu (Luk. 2:30); Sebab Anak Manusia... dan menyelamatkan yang hilang (Luk. 19:10); Aku datang untuk menyelamatkan dunia (Yoh. 12:47); Keselamatan tidak ada di dalam siapa pun juga selain di dalam Dia (Kis. 14:12); Yesus yang menyelamatkan kita dari murka yang akan datang (1 Tes. 1:10); Kristus Yesus datang ke dunia untuk menyelamatkan orang berdosa (1 Tim. 1:15); dan lain-lain.

\footnotetext{
${ }^{16}$ Lesslie Newbigin, Injil dalam Masyarakat Majemuk, (Jakarta: BPK Gunung Mulia, 1993),
} 236-237.

$$
\begin{array}{ll}
17 & \text { Ibid } \\
18 & \text { Ibid }
\end{array}
$$


Dari ayat-ayat ini mengungkapkan bahwa jalan keselamatan hanya mungkin oleh penebusan yang telah dikerjakan oleh Yesus Kristus, yang menebus kita dari murka Allah (1 Tes. 1:10). Dengan demikian keselamatan berarti bahwa hukuman dan penghakiman Allah diangkat dari manusia berdosa. Secara etimologi alkitabiah, keselamatan berbicara tentang keberadaan manusia yang terikat oleh dosa, yang terperangkap di dalam kematian dan melalui karya Kristus dalam kematian-Nya, menang terhadap kuasa-kuasa itu dan menyelamatkan serta membebaskan umat-Nya dari kuasa Setan (Mark. 3:23-27; Yoh. 8:32; Kis. 2:40; Rom. 5:9, 6:17-18; Gal. 5:1; Kol. 1:13; 1 Tes. 1:10; Ibr. 2:14-15; 1 Tim. 1:15; 2:4-5).

Dengan demikian keselamatan meliputi perubahan status sekaligus perubahan keadaan. Keselamatan menurut pandangan Hick sangat lemah dan kurang mendasar dalam agama-agama, karena setiap agama mempunyai konsep etimologi sendiri yang berbeda-beda tentang keselamatan. Juga mengenai masalah tujuan akhir keadaan manusia dan masalah keselamatan dari setiap agama-agama itu sendiri. Maka tentulah usaha Hick untuk mempersatukan pandangan agama-agama itu menghasilkan penyimpangan dari agama-agama itu sendiri. ${ }^{19}$ demikian:

Mengenai usaha Hick untuk mempersatukan itu, Newbigin mengungkapkan

Kita juga menginginkan persatuan itu, dan kerena itu mencari kebenaran yang hanya dengannya umat manusia dapat menjadi satu. Kebenaran itu bukanlah suau doktrin atau pandangan dunia atau bahkan pengalaman keagamaan; kebenaran tentu saja tidak ditemukan dengan mengulang kata-kata benda abstrak seperti keadilan dan kasih; kebenaran adalah manusia Yesus Kristus yang di dalamnya Allah sedang memperdamaikan dunia. Kebenaran itu adalah pribadi konkrit, historis. ${ }^{20}$

Teori Hick ini hanyalah merupakan tindakan untuk menentang kemutlakan atau keabsolutan, keunikan dan finalitas Kristus. Dia menyodorkan suatu paham atau teori yang kedengarannya logis atau masuk akal yang dalam kenyataannya lebih mudah untuk menyesuaikan diri atau diterima. Gejala serupa ini merupakan bahaya yang dengan mudah merambat masuk ke dalam paham dunia modern dan gerejagereja masa kini, yaitu suatu roh yang memutarbalikkan kebenaran firman Tuhan dan roh yang berusaha menarik iman kekristenan untuk berbalik dari Allah yang benar, yang tidak dapat melihat dan menemukan kebenaran lagi dari sumber kebenaran itu sendiri. Keadaan seperti inilah yang disebut roh akhir zaman, yang banyak kita temui pada zaman sekarang. Dengan demikian konsep Hick tentang transformasi dari self-centeredness kepada Reality-centeredness hanya merupakan teori yang mustahil terwujud dalam kenyataannya.

19 David Ndoen, Pluralisme....., 73

${ }^{20}$ Lesslie Newbigin, Injil dalam..., 238-239 


\section{SIMPULAN}

Setelah disinggung sekilas-lintas tentang latar belakang Hick, yaitu dari segi biografinya dan revolusi Kopernikusnya yang merupakan titik balik dari paham Ptolomeus; serta setelah menyoroti secara alkitabiah terhadap konsep "keselamatan"nya, maka penulis menyimpulkan sebagai berikut:

1) Hick telah membuang atau meninggalkan landasan yang terpenting dalam Firman Tuhan atau tradisi kekristenan, yaitu dengan menyangkal keabsolutan, keunikan, dan finalitas Kristus. Dengan demikian dia tidak mengakui bahwa keselamatan hanya oleh penebusan Yesus Kristus.

2) Hick telah berusaha dengan kemampuan intelektualnya, melalui revolusi Kopernikusnya, menciptakan suatu teori "keselamatan" yang menurutnya berlaku bagi semua agama.

3) Paham/teori keselamatannya Hick tentang transformasi dari self-centeredness kepada reality-centeredness, patut ditolak karena sangat kontradiksi dengan Firman Tuhan (Alkitab).

\section{DAFTAR PUSTAKA}

Clark, Andrew D., 1995 Satu Allah, Satu Tuhan. Jakarta: BPK Gunung Mulia

Coward, Harold

1992 Pluralisme, Tantangan bagi Agama-agama. Yogyakarta: Kanisius

Ndoen, David

1995 "Mengenal Selintas Soteriologi Pluralisme" dalam K. Hadiwinoto, Pendidikan Teologi Injili Suatu Alternatif? Malang: Tunggal Murni

1996 "Pluralisme”, Diktat. Batu: STT “I-3”

Newbigin, Lesslie

1993 Injil dalam Masyarakat Majemuk. Jakarta: BPK Gunung Mulia

Smith, Wilfred C.,

1988 "Idolatry in Comparative Perspective" dalam John Hick \& P. F. Knitter (ed.), The Myth of Christian Uniqueness. London: SCM Press Ltd.

van Niftrik, G. C.,

1967 Dogmatika Masa Kini. Jakarta: BPK Gunung Mulia 